\title{
HUBUNGAN RIWAYAT MEROKOK DALAM KELUARGA DENGAN PERILAKU MEROKOK MAHASISWA KEPERAWATAN TASIKMALAYA POLTEKKES KEMENKES TASIKMALAYA
}

\author{
Yanyan Bahtiar $^{1}$, Siti Badriah ${ }^{2}$, Asep A.S. Hidayat ${ }^{3}$ \\ 1, 2, 3 Dosen Jurusan Keperawatan Poltekkes Kemenkes Tasikmalaya
}

\begin{abstract}
ABSTRAK
Rokok telah menjadi salah satu penyebab kematian terbesar di dunia. Meskipun banyak diperlihatkan propaganda bahaya merokok bagi kesehatan, sampai bahaya kematian, tetapi perilaku merokok sulit dilepaskan, termasuk oleh mahasiswa keperawatan. Banyak faktor yang melatarbelakangi seorang mahasiswa berperilaku merokok, salah satunya berasal dari pengaruh keluarga. Penelitian ini bertujuan untuk mengetahui hubungan riwayat merokok keluarga dengan perilaku merokok mahasiswa Keperawatan Tasikmalaya Poltekkes Kemenkes Tasikmalaya. Disain penelitian menggunakan deskriptif korelasional dengan pendekatan crossexional study. Sampel penelitian sebesar 42 responden dengan menggunakan teknik purposif sampling. Instrumen penelitian menggunakan kuesioner. Data dianalisis menggunakan uji chi-square dengan uji alternatif fisher. Hasil penelitian menunjukkan hampir seluruh keluarga mahasiswa mempunyai riwayat merokok $(85,7 \%)$, tetapi secara statistik variabel riwayat merokok keluarga tidak berhubungan secara signifikan dengan perilaku merokok mahasiswa Keperawatan Tasikmalaya $(\rho=0,665)$. Masa remaja dari mahasiswa merupakan masa pencarian identitas dan mulai ingin mencoba-coba sesuatu hal yang baru termasuk merokok. Orang tua kadang tidak menyadari bahwa setiap batang rokok yang dihisap tidak luput dari perhatian anaknya. Pengelola kampus dan keluarga diharapkan dapat bekerja sama dalam perubahan perilaku merokok dari mahasiswa. Penelitian ini bisa dijadikan data dasar penelitian selanjutkan yang mengarah pada intervensi untuk mengatasi perilaku merokok.
\end{abstract}

Kata Kunci : Perilaku Merokok, Riwayat Keluarga, Mahasiswa, Keperawatan.

\begin{abstract}
ABSTRAC
Smoking has become one of the biggest causes of death in the world. Although many propaganda shown the dangers of smoking to health, to the danger of death, but smoking behavior is difficult to remove, including by nurses students. Many factors behind a student smoking behavior. One of them may come from family influence. This study aimed to determine the Relationship History of Smoking on Family with Smoking Behavior on Nursing Students in Poltekkes Kemenkes Tasikmalaya. Research design using descriptive correlational study crossexional approach. The research sample of 42 respondents using purposive sampling technique. The research instrument used questionnaire. Data were analyzed using chi-square test with the alternative is fisher's exact test. The results showed that family smoking history variables not related of significantly to smoking behavior on nursing students of Tasikmalaya $(\rho=0.665)$, but almost all students have a family history of smoking $(85.7 \%)$. Adolescence is atime of the search of the student's identity and began to want to try something new, including smoking. Parents sometimes do not realize that each of cigarettes smoked did not escape his attention. The campus and families are expected to cooperate in changing smoking behavior of students. This research can be used as basic data further research leading to interventions to address smoking behavior.
\end{abstract}

Keywords: Smoking Behavior, Family History, Student, Nursing. 


\section{PENDAHULUAN}

Rokok menjadi salah satu penyebab kematian terbesar di dunia. Menurut World Health Organization (WHO), diperkirakan menjelang tahun 2030 kematian akibat rokok akan mencapai 10 juta pertahun. Jumlah kematian akibat rokok di Indonesia menduduki peringkat ketiga di dunia setelah China dan India. Hasil Riset Kesehatan Dasar tahun 2010 menyebutkan bahwa $34,7 \%$ penduduk di Indonesia berusia 10 tahun ke atas adalah perokok aktif (Kemenkes, 2010). Rokok juga dapat menjadi pencetus berbagai macam penyakit seperti penyakit paru obstruksi kronik, penyakit kardiovaskuler dan sejumlah kanker tertentu (Depkes, 2007).

Rokok dengan segala masalahnya bukanlah menjadi sesuatu yang baru diketahui oleh seorang perawat. Perawat dibekali dengan berbagai konsep pengetahuan kesehatan, termasuk masalah kesehatan akibat rokok. Perawat mempunyai posisi yang unik dalam masyarakat, karena mempunyai peran dan fungsi dalam memandirikan masyarakat mencapai derajat kesehatan yang ideal baik secara individu, keluarga, kelompok khusus ataupun komunitas.

Kebiasaan dan gaya hidup merokok di perguruan tinggi juga makin banyak dijumpai, baik di jurusan kesehatan maupun jurusan bukan kesehatan. Walaupun kawasan tanpa rokok dalam peraturan bersama Menkes dan Mendagri tahun 2011 jelas dinyatakan salah satunya adalah tempat belajar mengajar, termasuk lingkungan kampus (Kemenkes, 2011). Hasil penelitian Musdalifah dan Setijadi (2011), mengungkapkan bahwa latar belakang pendidikan tidak berpengaruh secara signifikan terhadap perilaku merokok. Mahasiswa kesehatan (44,2\%) dan non kesehatan $(46,7)$ Universitas Sebelas Maret Surakarta sama banyaknya berperilaku sebagai perokok aktif. Konsumsi rokok di kalangan mahasiwa Indonesia cenderung meningkat setiap tahunnya. Terjadi kenaikan secara signifikan rata-rata frekuensi merokok di kalangan mahasiswa pada tahun 2009, yakni $24,5 \%$ mahasiswa dan 2,3\% mahasiswi (Dimyati, 2011).

Begitu juga yang terjadi di lingkungan Civitas Akademika Politeknik Kesehatan Kementerian Kesehatan Tasikmalaya, berdasarkan hasil survai peneliti tahun 2013 pada 213 mahasiswa Prodi D3 Keperawatan Tasikmalaya tingkat I dan II menggambarkan yang masih berperilaku merokok sebanyak 42 (20\%) mahasiswa dan yang pernah merokok tapi sudah berhenti sebanyak 39 mahasiswa. Banyak faktor yang melatarbelakangi seseorang berprilaku merokok, salah satunya mungkin terjadi dari lingkungan keluarga. Keluarga merupakan tempat pertama bagi seorang anak mendapatkan pendidikan, dan orang tua menjadi contoh perilaku bagi anakanaknya. Berdasarkan fenomena tersebut peneliti tertarik untuk melakukan penelitian mengenai hubungan riwayat merokok keluarga dengan perilaku merokok mahasiswa Keperawatan Tasikmalaya Poltekkes Kemenkes Tasikmalaya.

\section{METODE PENELITIAN}

Desain penelitian ini merupakan penelitian deskriptif corelational dengan pendekatan crossexional study, dimana pengambilan data dari tiap variabel dilakukan secara bersamaan.

Pengambilan sampel dengan cara purfosive sampling. Ukuran sampel adalah sampel populasi yaitu sebanyak 42 responden yang telah memenuhi kriteria penelitian (inklusi dan ekslusi). Kriteria inklusi; bersedia menandatangi informed consent, tercatat sebagai mahasiswa Keperawatan Tasikmalaya sampai tahun 2014, dan masih berperilaku merokok.

Instrumen penelitian yang digunakanan adalah kuesioner. Instrumen ini tidak perlu diuji lagi, karena tiap soal langsung mengidentifikasi isi setiap variabel.

Setelah mendapat menjelasan, responden mengisi lembar persetujuan menjadi peserta penelitian kemudian dilanjutkan mengisi kuesioner. Data yang 
dikumpulkan adalah data yang didapatkan melalui penilaian terhadap hasil pengisian kuesioner oleh responden. Data dikumpulkan langsung oleh tim peneliti. Data diedit dari kesalahan pengisian, kemudian diberikan kode untuk dianalisa, lalu ditransfer ke pengolahan komputer dan hasilnya ditampilkan dalam bentuk tabel.

Setelah diketahui distribusi frekuensi data masing-masing variabel, selanjutnya dilakukan analisis bivariat dengan crosstabulation. Pada penelitian ini kedua variabel berbentuk kategorik maka uji statistik yang digunakan adalah uji crosstabulation dengan Chi Square. Karena dengan uji Chi Square tidak memenuhi syarat, maka dilanjutkan dengan uji alternatifnya yaitu uji Fisher.

\section{HASIL PENELITIAN}

\section{Karakteristik Responden}

Tabel 1. Distribusi Karakteristik Mahasiswa Keperawatan Tasikmalaya Poltekkes Kemenkes Tasikmalaya

\begin{tabular}{llcc}
\hline No. & Karakteristik Responden & Frekuensi & Persentasi \\
\hline \multicolumn{4}{c}{ Jenis Kelamin } \\
\hline 1. & Laki-laki & 42 & $100 \%$ \\
\hline 2. & Perempuan & 0 & $0 \%$ \\
\hline \multicolumn{2}{c}{ Jenjang Pendidikan D3 Keperawatan } & & \\
\hline 1. & Kep.TK. II & 24 & $57,1 \%$ \\
\hline 2. & Kep.TK III & 18 & $42,9 \%$ \\
\hline
\end{tabular}

Distribusi karakteristik reponden pada tabel 1, dilaporkan bahwa semua responden penelitian berjenis kelamin laki-laki (100\%) dan sebagian besar responden adalah mahasiswa keperawatan tingkat II (57,1\%).

\section{Riwayat Merokok Keluarga Mahasiswa Keperawatan Poltekkes Kemenkes Tasikmalaya}

Riwayat merokok keluarga dapat dilihat pada tabel 2. Responden dengan keluarga perokok lebih banyak dibandingkan keluarga bukan perokok, masing-masing sebesar 36 $(85,7 \%)$ responden dan $6 \quad(14,3 \%)$ responden.

Tabel 2. Distribusi Riwayat Merokok Keluarga Mahasiswa Keperawatan Poltekkes Kemenkes Tasikmalaya.

\begin{tabular}{cccc}
\hline No. & $\begin{array}{c}\text { Riwayat Merokok } \\
\text { Keluarga }\end{array}$ & Frekuensi & Presentasi \\
\hline 1. & Tidak Ada Riwayat Merokok & 6 & $14,3 \%$ \\
\hline 2. & Ada Riwayat Merokok & 36 & $85,7 \%$ \\
\hline & Jumlah & $\mathbf{4 2}$ & $\mathbf{1 0 0 \%}$ \\
\hline
\end{tabular}




\section{Perilaku Merokok Mahasiswa Keperawatan Poltekkes Kemenkes Tasikmalaya}

Tabel 3. Distribusi Perilaku Merokok Mahasiswa Keperawatan Poltekkes Kemenkes Tasikmalaya

\begin{tabular}{cccc}
\hline No. & Perilaku Merokok & Frekuensi & Presentasi \\
\hline 1. & Perokok Ringan & 22 & $52,4 \%$ \\
\hline 2. & Perokok Sedang & 20 & $47,6 \%$ \\
\hline & Jumlah & $\mathbf{4 2}$ & $\mathbf{1 0 0 \%}$ \\
\hline
\end{tabular}

Perilaku merokok mahasiswa Keperawatan Poltekkes Kemenkes Tasikmalaya dapat dilihat pada tabel 3 . Pengukuran perilaku merokok dilakukan dengan menghitung rata-rata banyaknya batang rokok yang dihisap responden dalam
24 jam. Responden dengan perilaku perokok ringan sedikit lebih banyak dibandingkan dengan responden yang berperilaku perokok sedang yaitu masingmasing sebesar $22(52,4 \%)$ responden dan $20(47,6 \%)$ responden.

\section{Hubungan Riwayat Merokok Keluarga dengan Perilaku Merokok Mahasiswa Keperawatan Tasikmalaya Poltekkes Kemenkes Tasikmalaya}

Tabel 4. Hubungan Riwayat Merokok Keluarga dengan Perilaku Merokok Mahasiswa Keperawatan Tasikmalaya Poltekkes Kemenkes Tasikmalaya.

\begin{tabular}{lccccc}
\hline \multirow{2}{*}{ No. } & $\begin{array}{c}\text { Riwayat Merokok pada } \\
\text { Keluarga }\end{array}$ & \multicolumn{2}{c}{ Perilaku Merokok } & \multirow{2}{*}{ Jumlah } & \multirow{2}{*}{$\boldsymbol{P}$} \\
\cline { 3 - 5 } & Ringan & Sedang & & \\
\hline 1. & Tidak Ada Riwayat & $4(66,7 \%)$ & $2(33,3 \%)$ & $6(100 \%)$ & 0,665 \\
\cline { 1 - 4 } 2. & Ada Riwayat & $18(50 \%)$ & $18(50 \%)$ & $36(100 \%)$ & \\
\cline { 1 - 4 } & Jumlah & $22(52,4 \%)$ & $20(47,6 \%)$ & $42(100 \%)$ & \\
\hline
\end{tabular}

Hubungan antara riwayat merokok keluarga dengan perilaku merokok mahasiswa Keperawatan Tasikmalaya Poltekkes Kemenkes Tasikmalaya dapat dilihat pada tabel 4. Hasil analisis diperoleh data bahwa pada mahasiswa yang keluarganya tidak merokok terdapat 4 $(66,7 \%)$ mahasiswa perokok ringan dan 2 $(33,3 \%)$ mahasiswa perokok sedang. Pada mahasiswa yang keluarganya perokok

\section{PEMBAHASAN}

Perilaku merokok merupakan aktivitas rangsangan dari dalam maupun luar yang mempengaruhi seseorang merokok dan dapat diamati secara langsung. Asap rokok mengandung berbagai zat kimia yang berbahaya untuk kesehatan, diantaranya adalah nikotin bersifat adiktif dan tar bersifat terdapat masing-masing $18 \quad$ (50\%) mahasiswa perokok ringan maupun perokok sedang. Hasil uji statistik diperoleh nilai $p=0,665(\alpha=5 \%)$, maka dapat disimpulkan bahawa $\mathrm{H}_{0}$ gagal ditolak artinya tidak ada hubungan yang signifikan antara riwayat merokok keluarga dengan perilaku merokok mahasiswa Keperawatan Tasikmalaya Poltekkes Kemenkes Tasikmalaya.

karsinogenik. Meski semua orang tahu bahaya yang ditimbulkan asep rokok, perilaku merokok tidak pernah surut dan tampak perilaku yang masih ditolerir oleh sebagian besar masyarakat.

Permasalahan perilaku merokok sekarang ini bukan saja menjadi tanggung 
jawab sektor kesehatan, melainkan tanggung jawab berbagai sektor terkait. Pemerintah sudah mengeluarkan berbagai peraturan yang meregulasi perilaku merokok, diantaranya adalah menetapkan Kawasan Tanpa Rokok (KTR) di fasilitas pelayanan kesehatan, tempat belajar mengajar termasuk kampus, tempat ibadah, tempat umum, angkutan umum, tempat bermain anak dan tempat kerja. Begitu juga dengan informasi tentang rokok dan kerugian yang ditimbulkannya telah banyak disampaikan, termasuk dalam kemasan rokok. Propaganda kesehatan tersebut sering diabaikan sehingga semakin banyak orang yang merokok, termasuk para remaja atau mahasiswa. Mahasiswa merupakan masa remaja dimana individu berada pada ambang dewasa sehingga masa mahasiswa mulai memusatkan diri pada perilaku yang dihubungkan dengan status dewasa seperti halnya perilaku merokok. Mahasiswa menganggap bahwa perilaku tersebut akan memberikan citra seperti yang mereka inginkan yaitu dianggap sebagai individu yang telah dewasa.

Perilaku merokok orang tua sangat memengaruhi perilaku merokok anaknya, seperti penelitian Lindawati (2012), adanya hubungan yang bermakna antara perilaku orang tua yang merokok dengan perilaku merokok responden. Bandura menegaskan bahwa perilaku anak terbentuk karena mencontoh (modelling) dan contoh yang paling cepat ditiru adalah contoh yang bersumber dari orang yang paling bermakna dalam kehidupannya yaitu keluarga. Melalui keluarga anak belajar bertingkah laku sosial. Karena betapa mudah anak meniru perilaku orang tuanya (Satiadarma, 2001).

Perilaku merokok juga dipengaruhi oleh lingkungan sosial dan keluarga terutama orang tua. Evans et al dalam De Vries menyatakan bahwa faktor sosial berpengaruh secara langsung dan tidak langsung pada individu. Penelitian Kristanti dan Wismanto (2000) menunjukkan bahwa orang tua yang merokok memiliki kecenderungan untuk permisif terhadap anak yang merokok daripada ayah yang tidak merokok. Hal tersebut terjadi karena orang tua yang merokok tidak memiliki kekuatan moral, sosial dan psikis untuk melarang anaknya. Sebaliknya, orang tua yang tidak merokok mampu melarang anaknya untuk tidak merokok karena mereka mampu melakukan hal yang sama dan memberikan contoh yang baik (Wismanto dan Sarwo, 2007). Perkataan atau nasihat orang tua idelanya harus sama dengan apa yang diperbuatnya.

Keluarga yang terbiasa dengan perilaku merokok dan menjadi permisif dengan hal tersebut sangat berperan untuk menjadikan anaknya perokok. Kebiasaan merokok pada orang tua berpengaruh besar pada anak-anaknya yang berusia remaja. Masa remaja merupakan masa pencarian identitas dan masa mulai ingin mencobacoba sesuatu hal yang baru termasuk merokok. Orang tua terkadang tidak menyadari bahwa setiap kepulan asap yang dihembuskan dari sebatang rokok yang dihisapnya tidak luput dari perhatian anak.

Perilaku modeling merupakan perilaku dari model yang ditiru dimana memanfaatkan proses belajar melalui pengamatan atau proses menirukan tingkah laku orang lain. Salah satu model yang ditiru adalah perilaku orang tua yang berada di lingkungan keluarga. Orang tua sebagai panutan bisa menjadi figur yang akan ditiru perilakunya. Tidak hanya perilaku yang baik, tetapi perilaku yang tidak baik pun bisa ditiru.

Tidak hanya perilaku merokok orang tua saja yang dapat ditiru anak remaja, tetapi gaya merokok juga bisa ditirunya. Kebiasaan merokok orang tua seperti merokok setelah makan atau merokok ditemani dengan segelas kopi dapat memengaruhi remaja untuk melakukan hal yang sama. Bahkan merek rokok orang tuanya dapat memberikan inspirasi pada anak remaja untuk membeli rokok dengan merk yang sama.

Rochadi (2004), menyatakan bahwa proporsi terbesar kelompok remaja perokok berat adalah yang memiliki ayah perokok, dengan melihat proporsi cukup besar dapat 
diasumsikan orang tua perokok memberikan kontribusi yang besar kepada anaknya untuk merokok. Seperti dalam penelitian ini walaupun secara statistik riwayat merokok keluarga tidak berhubungan dengan perilaku merokok mahasiswa tetapi sebagian besar dari responden mahasiswa keluarganya perokok. Hasil penelitian ini sejalan dengan penelitian yang dilakukan oleh Musdalifah dan Setijadi di Universitas Sebelas Maret Surakarta pada tahun 2011, menunjukkan bahwa secara statistik tidak ada hubungan antara status merokok orang tua dengan perilaku merokok mahasiswa kedokteran (Musdalifah dan Setijadi, 2011).

Peran serta keluarga dan pengelola lingkungan kampus dalam memberikan contoh perilaku tidak merokok serta menggiatkan kembali akan bahaya rokok perlu ditingkatkan. Bahaya rokok tidak saja beresiko pada diri sendiri tapi juga bagi orang lain yang ada di sekitarnya. Mahasiswa sebagai generasi penerus pembangunan bangsa dan juga agen

\section{KESIMPULAN}

Distribusi karakteristik responden berdasarkan jenis kelamin dan tingkat pendidikan adalah semua responden lakilaki, dan mahasiswa tingkat II sedikit lebih banyak dari tingkat III.

Responden dengan tingkat perilaku merokok ringan sedikit lebih banyak dibandingkan dengan responden tingkat perilaku merokok sedang. Responden yang

\section{REFERENSI}

Depkes. RI., (2007). Dirjen Pengendalian Penyakit dan Penyehatan Lingkungan. Direktorat Pengendalian Penyakit Tidak Menular. Pedoman Pengendalian Penyakit Paru Obstruktif Kronik (PPOK). Jakarta: Depkes. RI.

Dimyati, V., (2011). Perokok aktif terus meningkat. Diunduh tgl. 20 Mei 2013 dari http://www.nasional.jurnas.com

Kemenkes. (2011). Peraturan Bersama Menkes dan Mendagri. No.188/MENKES/ PB/I/2011 dan perubah diharapkan dapat berhenti dari perilaku merokok.

Berhenti merokok bukan sesederhana seperti mengganti rokok dengan yang lain, seperti fenomena sekarang ini banyak yang beralih ke rokok herbal, tapi intinya tetap merokok dan perlu dikaji lebih dalam lagi apa sebenarnya rokok herbal tersebut. Untuk bisa mengurangi perilaku merokok perlu adanya motivasi dari diri sendiri yang dimulai secara bertahap sampai tidak merokok sama sekali dengan pertimbangan akan bahaya yang di timbulkan akibat rokok. Berhenti merokok akan menyentuh aspek kejiwaan yang sangat mendasar yang mungkin selama ini telah memberikan rasa ketenangan dan kesenangan. Dengan adanya penyuluhan kesehatan tentang bahaya rokok, pemasangan poster-poster anti rokok, kebijakan larangan merokok dan memberikan motivasi tentang berhenti merokok diharapkan mahasiswa mampu mengurangi perilaku merokok secara bertahap sampai tidak merokok sama sekali.

memiliki keluarga dengan riwayat merokok baik ayah atau kakaknya lebih banyak dibandingkan dengan responden yang riwayat keluarganya tidak merokok.

Secara statistik tidak ada hubungan yang signifikan antara riwayat merokok keluarga dengan perilaku merokok mahasiswa Keperawatan Tasikmalaya Poltekkes Kemenkes Tasikmalaya.

Nomor 7 Tahun 2011 Tentang pedoman pelaksanaan kawasan tanpa rokok. Jakarta: Kemenkes. RI.

Kemenkes. (2010). Laporan Hasil Riskesdas Tahun 2010. Jakarta: Kemenkes. RI.

Lindawati, Miradwiyana \& Sumiati, (2012). Faktor-faktor yang mempengaruhi perilaku merokok siswa-siswi SMP di Jakarta selatan tahun 2011. Jurnal Health Quality Vol.2 No.4, Mei 2012. Jakarta: Poltekkes Kemenkes Jakarta I 
Musdalifah dan Setijadi, A.R., (2011).

Pengaruh latar belakang pendidikan, stres, orang tua, teman, dan iklan terhadap perilaku merokok pada mahasiswa Universitas Sebelas Maret Surakarta. J Respir Indo Vol. 31, No. 4, Oktober 2011.

Rochadi, K. (2004). Hubungan konformitas dan perilaku merokok pada remaja sekolah SMU negeri 5 di Wilayah DKI
Jakarta. Disertai program

Pascasarjana. Program studi IKM UI.

Satiadarma, M.P. (2001). Persepsi orangtua membentuk perilaku anak. Jakarta: Pustaka Populer Obor.

Wismanto dan Sarwo, (2007). Strategi penghentian perilaku merokok. Semarang: Unika Soegijapranata. Diakses pada tanggal 2 Februari 2015 dari http://eprints.unika.ac.id 